\title{
Public attitude towards biomedical research at outpatient clinics of King Abdulaziz medical city, Riyadh, Saudi Arabia
}

M. Al-Jumah, ${ }^{7}$ M.A. Abolfotouh, ${ }^{7}$ I.B. Alabdulkareem, ${ }^{7}$ H.H. Balkhy, ${ }^{1}$ M.I. Al-Jeraisy, ${ }^{7}$ A. F. Al-Swaid, ${ }^{1}$ E.M. Al-Musaaed ${ }^{1}$ and B. Al-Knawy

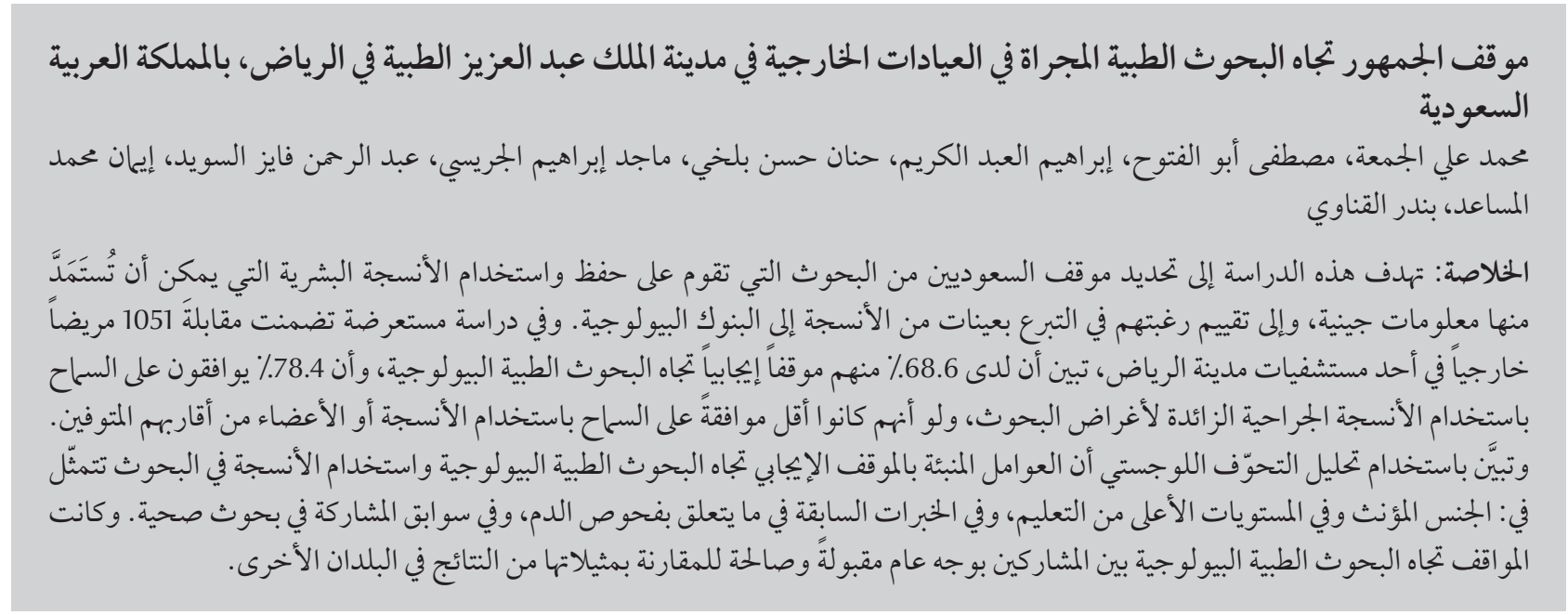

ABSTRACT The aim of this study was to determine the attitude of Saudi Arabians to research involving storage and use of human tissues from which genetic information may be derived and to assess their willingness to donate tissue samples to biobanks. In a cross-sectional interview study of 1051 outpatients at a hospital in Riyadh city, $68.8 \%$ had a positive attitude towards biomedical research and $78.4 \%$ were willing to allow use of excess surgical tissues for research purposes. Participants were less willing to allow the use of tissue or organs from a deceased relative. Logistic regression analysis found that predictors for a positive attitude to biomedical research and to use of tissue in research were: female sex, higher level of education, previous experience of blood testing and previous participation in health-related research. The attitudes towards biomedical research among the participants were satisfactory and comparable to findings from other countries.

\section{Attitude d'une population de patients dans un centre de consultations externes de King Abdulaziz medical} city, à Riyad (Arabie saoudite) au sujet de la recherche biomédicale

RÉSUMÉ L'objectif de la présente étude était d'identifier l'attitude de Saoudiens au sujet de la recherche impliquant la conservation et I'utilisation de tissus humains à partir desquels des informations génétiques pourraient être extraites, et d'évaluer leur disposition à faire don d'échantillons de tissus à des biobanques. Une étude transversale comportant des entretiens a montré que 68,8 \% des 1051 patients interrogés en consultation externe dans un hôpital de Riyad montraient une attitude positive au sujet de la recherche biomédicale. D'autre part, 78,4 \% d'entre eux étaient disposés à autoriser l'utilisation des déchets chirurgicaux à des fins de recherche. Les participants étaient moins enclins à autoriser l'utilisation de tissus ou d'organes provenant d'un membre décédé de leur famille. L'analyse de régression logistique a indiqué que les facteurs prédictifs d'une attitude positive au sujet de la recherche biomédicale et de l'utilisation des tissus pour la recherche étaient les suivants : sexe féminin, haut niveau d'études, analyses de sang préalables et participation à une étude de recherche dans le domaine de la santé. L'attitude des participants au sujet de la recherche biomédicale était satisfaisante et comparable aux résultats d'autres pays. 


\section{Introduction}

The rapid development of biotechnological research has stimulated the use ofbiobanks that store biological samples and allow for identification of disease genes, which could lead to more personalized health prevention programmes and treatments [1]. Combining health and genetic data from large populations also means that the complex relationships between genes, environment and disease can be explored [1]. Human tissue may be obtained after death or from living donors. Retention of organs and tissue for research can take place after death if relatives give their consent. For the living, samples of human tissue are often available after surgery. Not all of this tissue is needed for diagnosis and other clinical care and excess tissue samples from surgery may be stored as part of a patient's medical record [2].

Biobanks depend on people's willingness to contribute samples for both research and storage. Public support is thus essential in securing the long-term viability of biobanks [3]. In a survey of the general population in Ireland, the majority of those surveyed had not heard of any medical or health-related research conducted in Ireland in the previous 3 months and less than 10\% had participated in a medical or health research study [4].

Involving public opinion allows for more informed decision-making [3]. Knowledge of the public perspective, and of factors that influence their willingness to donate tissue samples, may inform the governance of biobanks and the design of information and consent procedures [5]. The public's willingness to contribute to genetic research is relatively high according to some American [6-9] and Asian [10] studies. The characteristics of those in favour of donation include older age [8], higher education, a positive family history of a genetic disorder, a belief that genetic research will benefit people, a willingness to participate in government research on health
$[8,10]$, a belief in genetic determinism $[7,8]$, having no fear of blood, injections or needles, and a lack of concern about loss of confidentiality [10].

Different cultures have different views on science, research and genetic discovery. Religious views especially must be considered when planning biobanks because these may influence issues of informed consent and concerns about justice $[11,12]$. There has been little research examining the circumstances under which Saudi Arabian people would be willing to allow epidemiological investigators to use their private information and biological samples for research. We do not know whether or not Saudilay people approve of the kinds of ethical guidelines that are widely accepted among health care professionals elsewhere. Saudi Biobank is planned as a prospective study, with an expected sample of 200000 subjects, to examine the interactions between genes, environment and lifestyle in a range of common late-onset diseases [13]. The costs associated with establishing such a cohort mean that it is essential to make recruitment as successful and cost-effective as possible. It is therefore important to identify the determinants of whether a person approached is willing to be part of Saudi Biobank or not.

The objectives of this study therefore were: to identify the attitude of a sample of Saudi Arabians regarding research involving storage and use of human tissues from which genetic information may be derived; to assess their willingness to donate tissue samples to biobanks; to identify significant predictors for a positive attitude to biomedical research and to the willingness to donate tissue samples; and to assess the level of feedback on research findings considered desirable by the public.

\section{Methods}

A cross-sectional study was conducted on a sample selected from among adults attending outpatient clinics at King Abdulaziz Medical City, Riyadh city. Due to their engagement with the health service this group were expected to be supportive of medical research, with high levels of willingness to contribute excess surgical tissue for research. In a survey of the general population in Ireland, less than $10 \%$ had participated in a medical or health research study [4]. Based on an average proportion of $10 \%$ for participation in biomedical research, a precision of $2 \%$, with $95 \%$ confidence limits, the estimated sample size was 864. Thus, to compensate for questionnaires with incomplete responses, a total sample of 1200 adult subjects, aged $18+$ years of both sexes was the target sample for the present study.

A period of 2 weeks ( 10 working days) was allocated for data collection. Thus, an average of 120 questionnaires daily were expected to be completed by data interviewers. A total of 5 data collectors (2 research coordinators and 3 research assistants) at King Abdullah International Medical Research Centre were trained to conduct the interview. Each data collector was responsible for conducting interviews with 24 subjects daily for 10 days. Subjects were chosen at random from among those who were willing to participate in the study at the waiting areas of different outpatient clinics of King Abdulaziz Medical City.

\section{Interview schedule}

Since not all the aims of this study could be adequately addressed by any one existing research questionnaire, a specific interview schedule was devised. The interview schedule was informed where relevant by other research questionnaires. Use of questions from relevant international questionnaires was considered to maximize the comparability of the data collected in this study $[4,14]$. The interview questionnaire was translated into Arabic. Test-retest reliability was ensured in a pilot study of 20 subjects the day before starting data collection. The content validity 
and feasibility of the questionnaire was ensured through negotiations with various relevant experts at King $\mathrm{Ab}$ dullah International Medical Research Centre, to ensure the relevancy and clarity of questions. Several additions and amendments were made to ensure that they questions were valid in a Saudi context.

The interview schedule was composed of 3 parts:

\section{Part 1: General information related to biomedical research and biobanking}

This part was separated into 5 sections that covered the following aspects: personal characteristics and health status; experience of blood or organ donation (whether participants had ever had a blood or other medical tests or donated blood/were willing to donate blood); experience of participation in medical or health-related research; organ retention (whether they heard of organ retention, had they talked about the issue with anyone, had they read newspaper articles or listened to the radio reports about the issue); and desire for feedback about their results.

\section{Part 2: Attitude to biomedical research scale}

This was 10-item attitude statement scale that used a 5-point Likert scale to evaluate participants' attitudes towards and beliefs about biomedical research. The statements were concerned with: beliefs about medicines and medical research; attitudes to genetic research; willingness to contribute tissue samples to medical research; and desire for feedback about the results. Participants gave strongly agree, agree, not sure, disagree or strongly disagree responses to all questions. Negative attitude statements were scored from 1 (strongly agree) to 5 (strongly disagree). The reverse of this scoring system was used for positive attitude statements. Accordingly, the maximum total score for attitude questions was 50 and the minimum was 10 . The total score of items were divided by the number of items in the scale to obtain a mean subscale score. For every person, the percentage of attitude was calculated as follows: percentage of attitude $=$ (sum of the attitude score) maximum total score) $\times 100$. A percentage score $<60 \%$ was considered negative, $60 \%$ or more was considered positive [15].

\section{Part 3: General-harm subscale of beliefs about medication:}

Participants' beliefs about medicines were assessed using the general-harm subscale of the beliefs about medication questionnaire (BMQ) $[16,17]$. Participants indicated their degree of agreement with 4 statements about medicines on a 5-point scale. These responses were summed to create a general harm sub-scale score, which ranged from 4 to 20 . A score of 20 indicated complete agreement with the concept that medicines are harmful, addictive, should not be taken for long periods and/or are less safe than natural remedies. Subjects with total harm scores of $<12$ points $(\leq 60 \%$ of total score) were categorized as low, 12-15 points as moderate and $16+$ points as high harm belief scorers.

Training sessions were organized for interviewers covering the issues of medical research using human tissue, recent controversies on these issues reported in the media, areas where particular sensitivity was needed and detailed instructions on conducting the interviews. Interviewers were instructed on their role and responsibilities, including ensuring their own safety. Field data collection was supervised by the investigators for 1 month, to ensure procedures were followed correctly. Daily meeting sessions were held between the data collectors and field supervisors following field activities to solve problems, to check the accuracy and completeness of the data collection forms and to emphasize standardization of procedures.

\section{Ethical considerations}

Participants' identity and their address were unknown to the research team.
Any participants had the right not to participate in the study or to withdraw during the interview without completion.

The study protocol \# RR08/018 received ethical approval from the institutional review board of the National Guard Health Affairs, Riyadh, Saudi Arabia.

\section{Statistical analysis}

Completing the survey involved initially ranking each positive statement on a Likert scale from 0 (strongly disagree) to 4 (strongly agree). Negarive statements were reverse scored. SPSS, version 17 was used for data analysis.

The chi-squared test was used as a test of significance to compare categorical data. The Mann-Whitney test, Kruskal-Wallis test and Pearson correlation were used as tests of significance to compare numerical data.

Multivariate analyses were performed with logistic regression models to determine significant predictors of a positive attitude to biomedical research and to willingness of the participant to donate surgical tissues. The choice of the variables in the model was based on the results of univariate analyses, where only the significant variables in univariate analyses were entered in the logistic regression analysis.

For all statistical analyses, a $P$-value $<0.05$ was considered significant.

\section{Results}

\section{Personal characteristics and health status}

The study sample of 1051 respondents comprised $53.1 \%$ men and $46.9 \%$ women. Table 1 shows the distribution of the study sample according to their personal characteristics (age, sex, education, employment and marital status), as well as their health status (perception of own health, presence of chronic disease and previous hospitalization). Women were statistically 


\begin{tabular}{|c|c|c|c|c|c|c|}
\hline \multirow[t]{2}{*}{ Characteristic } & \multicolumn{2}{|c|}{$\begin{array}{c}\text { Males } \\
(n=558)\end{array}$} & \multicolumn{2}{|c|}{$\begin{array}{l}\text { Females } \\
(n=493)\end{array}$} & \multicolumn{2}{|c|}{$\begin{array}{c}\text { Total } \\
(n=1051)\end{array}$} \\
\hline & No. & $\%$ & No. & $\%$ & No. & $\%$ \\
\hline \multicolumn{7}{|l|}{ Age group (years) } \\
\hline$<40$ & 475 & 85.1 & 431 & 87.8 & 906 & 86.4 \\
\hline $40+$ & 83 & 14.9 & 60 & 12.2 & 143 & 13.6 \\
\hline$P$-value ${ }^{\mathrm{a}}$ & \multicolumn{6}{|c|}{$\chi^{2}=1.53, P=0.22$} \\
\hline \multicolumn{7}{|l|}{ Marital status } \\
\hline Married & 322 & 58.2 & 269 & 55.0 & 591 & 56.7 \\
\hline Single & 220 & 39.8 & 189 & 39.7 & 409 & 39.3 \\
\hline Widowed/divorced & 11 & 2.0 & 31 & 6.3 & 42 & 4.0 \\
\hline$P$-value & \multicolumn{6}{|c|}{$\chi^{2}=12.74, P=0.002$} \\
\hline \multicolumn{7}{|c|}{ Current employment status } \\
\hline At work & 466 & 85.0 & 279 & 56.9 & 745 & 71.8 \\
\hline Unemployed & 16 & 2.9 & 46 & 9.4 & 62 & 6.0 \\
\hline Student & 61 & 11.1 & 81 & 16.5 & 142 & 13.7 \\
\hline Retired & 5 & 0.9 & 2 & 0.4 & 7 & 0.7 \\
\hline Home duties & - & - & 82 & 16.7 & 82 & 7.9 \\
\hline$P$-value ${ }^{\mathrm{a}}$ & \multicolumn{6}{|c|}{$\chi^{2}=144.77, P<0.001$} \\
\hline \multicolumn{7}{|c|}{ Educational level completed } \\
\hline$<$ Secondary & 51 & 9.3 & 58 & 11.9 & 109 & 10.5 \\
\hline$\geq$ Secondary & 495 & 90.7 & 431 & 88.1 & 926 & 89.5 \\
\hline$P$-value ${ }^{\mathrm{a}}$ & \multicolumn{6}{|c|}{$\chi^{2}=1.91, P=0.17$} \\
\hline \multicolumn{7}{|l|}{ Having children } \\
\hline No & 259 & 48.6 & 233 & 48.6 & 492 & 48.6 \\
\hline Yes & 274 & 51.4 & 246 & 51.4 & 520 & 51.4 \\
\hline$P$-value ${ }^{\mathrm{a}}$ & \multicolumn{6}{|c|}{$\chi^{2}=0.01, P=0.99$} \\
\hline \multicolumn{7}{|c|}{ Perception of health status } \\
\hline Excellent/very good & 442 & 80.1 & 371 & 76.2 & 813 & 78.2 \\
\hline Good & 78 & 14.1 & 68 & 14.0 & 146 & 14.1 \\
\hline Fair/poor & 32 & 5.8 & 48 & 9.8 & 80 & 7.7 \\
\hline$P$-value ${ }^{\mathrm{a}}$ & \multicolumn{6}{|c|}{$\chi^{2}=6.04, P=0.049$} \\
\hline \multicolumn{7}{|c|}{ Presence of chronic disease } \\
\hline Yes & 65 & 11.8 & 86 & 17.5 & 151 & 14.5 \\
\hline No & 471 & 88.2 & 406 & 82.5 & 877 & 85.5 \\
\hline$P$-value & \multicolumn{6}{|c|}{$\chi^{2}=6.72, P=0.01$} \\
\hline \multicolumn{7}{|l|}{ Previous hospitalization } \\
\hline Yes & 248 & 44.7 & 286 & 58.4 & 534 & 51.1 \\
\hline No & 307 & 55.3 & 204 & 41.6 & 511 & 48.9 \\
\hline$P$-value ${ }^{\mathrm{a}}$ & \multicolumn{6}{|c|}{$\chi^{2}=19.50, P<0.001$} \\
\hline
\end{tabular}

Data missing in some catogories; percentages are calculated for those participants fro whom data were available. aPearson chi-squared.

significantly more likely than men to were significantly more likely to report report being a hospital inpatient $(58.4 \%$ being employed (85.0\% versus $56.9 \%$, versus $44.7 \%, P<0.001)$ and having a $\quad P<0.001)$ and perceiving their health chronic disease (17.5\% versus $11.8 \%$, as excellent/very good ( $80.1 \%$ versus $P<0.01)$. On the other hand, men $76.2 \%, P=0.049)$.
Experience with health care system \& participation in research

Table 2 shows the distribution of the study sample according to their 


\begin{tabular}{|c|c|c|c|c|c|c|}
\hline \multirow[t]{2}{*}{ Variable } & \multicolumn{2}{|c|}{$\begin{array}{c}\text { Males } \\
(n=558)\end{array}$} & \multicolumn{2}{|c|}{$\begin{array}{l}\text { Females } \\
(n=493)\end{array}$} & \multicolumn{2}{|c|}{ Total } \\
\hline & No. & $\%$ & No. & $\%$ & No. & $\%$ \\
\hline \multicolumn{7}{|l|}{ Previous blood testing } \\
\hline Yes & 433 & 77.7 & 385 & 78.6 & 818 & 78.1 \\
\hline No & 124 & 22.3 & 105 & 21.4 & 229 & 21.9 \\
\hline$P$-value & \multicolumn{4}{|c|}{$\chi^{2}=0.03, P=0.87$} & & \\
\hline \multicolumn{7}{|l|}{ Previous tissue testing } \\
\hline Yes & 26 & 4.7 & 56 & 11.4 & 82 & 7.8 \\
\hline No & 528 & 95.3 & 435 & 88.6 & 963 & 92.1 \\
\hline$P$-value & \multicolumn{4}{|c|}{$\chi^{2}=14.96, P<0.001$} & & \\
\hline \multicolumn{7}{|l|}{ Previous blood donation } \\
\hline Yes & 364 & 65.4 & 88 & 17.9 & 452 & 43.1 \\
\hline No & 193 & 34.6 & 403 & 82.1 & 596 & 56.9 \\
\hline$P$-value & \multicolumn{4}{|c|}{$\chi^{2}=239.32, P<0.001$} & & \\
\hline \multicolumn{7}{|c|}{ Previous tissue (organ) donation } \\
\hline Yes & 5 & 0.9 & 8 & 1.6 & 13 & 1.2 \\
\hline No & 545 & 99.1 & 483 & 98.4 & 1028 & 98.8 \\
\hline$P$-value & \multicolumn{4}{|c|}{$\chi^{2}=1.09, P=0.30$} & & \\
\hline \multicolumn{7}{|l|}{$\begin{array}{l}\text { Previous participation in } \\
\text { health-related research }\end{array}$} \\
\hline No & 436 & 78.6 & 394 & 80.2 & 830 & 79.3 \\
\hline Yes & 119 & 21.4 & 97 & 19.8 & 216 & 20.7 \\
\hline \multicolumn{7}{|c|}{$\begin{array}{l}\text { Awareness of organ retention } \\
\text { controversy }\end{array}$} \\
\hline No & 208 & 37.8 & 168 & 34.6 & 376 & 36.3 \\
\hline Yes & 335 & 62.5 & 317 & 65.4 & 659 & 63.7 \\
\hline$P$-value & \multicolumn{4}{|c|}{$\chi^{2}=1.13, P=0.29$} & & \\
\hline \multicolumn{7}{|c|}{ Desire for feedback about the findings } \\
\hline No. & 458 & 85.8 & 432 & 91.1 & 890 & 88.3 \\
\hline Yes & 76 & 14.2 & 42 & 8.9 & 118 & 11.7 \\
\hline$P$-value & \multicolumn{4}{|c|}{$\chi^{2}=7.01, P=0.008$} & & \\
\hline \multicolumn{7}{|l|}{ Beliefs about medicines } \\
\hline High harm scorers & 26 & 6.0 & 15 & 3.8 & 41 & 4.9 \\
\hline Moderate harm scorers & 147 & 33.9 & 146 & 36.9 & 293 & 35.3 \\
\hline Low harm scorers & 261 & 60.1 & 235 & 59.3 & 496 & 59.8 \\
\hline$P$-value & \multicolumn{4}{|c|}{$\chi^{2}=2.58, P=0.28$} & & \\
\hline
\end{tabular}

Data missing in some catogories; percentages are calculated for those participants fro whom data were available. aPearson chi-squared.

engagement with the health care system and the following reported health care experiences: blood tests (78.1\%), tissue testing $(7.8 \%)$, blood donation (43.1\%), tissue/organ donation (1.2\%), participation in health-related research (20.7\%), awareness of controversy about organ retention (63.7\%), desire for feedback of their results (11.7\%) and moderate to high harm beliefs about medicines (40.2\%). Males were significantly more likely to report previous blood donation than were women $(65.4 \%$ versus $17.9 \%)(P<0.001)$, while females were more likely to report previous tissue testing than males ( $11.4 \%$ versus $4.7 \%)(P<0.001)$. Using the belief about medication questionnaire, the study found a mean score of harm beliefs about medicines of 10.8 (SD 3.0) out of a total score of 20, indicating a slight tendency to agree with the general concept that medicines are harmful.

\section{Attitudes to biomedical and genetic research}

Table 3 shows the response of participants to 10 attitude statements describing various potential benefits and ethics of biomedical research. According to 


\begin{tabular}{|c|c|c|c|c|c|c|}
\hline Statement/sex & $\begin{array}{l}\text { Strongly } \\
\text { agree }\end{array}$ & Agree & Unsure & Disagree & $\begin{array}{l}\text { Strongly } \\
\text { disagree }\end{array}$ & Sex difference \\
\hline & $\%$ & $\%$ & $\%$ & $\%$ & $\%$ & \\
\hline \multicolumn{7}{|c|}{$\begin{array}{l}\text { New genetic developments will } \\
\text { result in cures for many diseases }\end{array}$} \\
\hline Male & 16.8 & 36.4 & 31.9 & 11.0 & 3.9 & \multirow[b]{2}{*}{$\chi^{2}=11.20, P=0.024$} \\
\hline Female & 23.6 & 37.9 & 28.1 & 7.3 & 3.2 & \\
\hline \multicolumn{7}{|c|}{$\begin{array}{l}\text { Researchers are mainly motivated } \\
\text { by selfish reasons (money) }\end{array}$} \\
\hline Male & 7.2 & 11.5 & 22.5 & 38.3 & 20.4 & \multirow{3}{*}{$\chi^{2}=15.06, P=0.005$} \\
\hline Female & 4.7 & 7.7 & 17.3 & 45.3 & 25.0 & \\
\hline Total & 6.1 & 9.7 & 20.1 & 41.6 & 22.6 & \\
\hline \multicolumn{7}{|c|}{$\begin{array}{l}\text { Research on human genetics is } \\
\text { tampering with reliqion }\end{array}$} \\
\hline Male & 4.3 & 9.2 & 38.3 & 26.2 & 22.1 & \multirow{3}{*}{$\chi^{2}=20.04, P<0.001$} \\
\hline Female & 4.9 & 5.7 & 28.5 & 36.2 & 24.7 & \\
\hline Total & 4.6 & 7.6 & 33.7 & 30.8 & 23.3 & \\
\hline \multicolumn{7}{|c|}{ Willing to donate blood in the future } \\
\hline Male & 63.1 & 25.7 & 4.7 & 3.7 & 2.8 & \multirow[b]{2}{*}{$\chi^{2}=16.90, P=0.002$} \\
\hline Female & 50.6 & 33.8 & 7.3 & 5.4 & 2.8 & \\
\hline \multicolumn{7}{|c|}{$\begin{array}{l}\text { Willing to allow use of own excess } \\
\text { surgical tissue in research }\end{array}$} \\
\hline Male & 30.3 & 33.6 & 11.9 & 13.6 & 10.6 & \multirow[b]{2}{*}{$\chi^{2}=23.99, P<0.001$} \\
\hline Female & 39.0 & 38.0 & 9.8 & 8.1 & 5.1 & \\
\hline \multicolumn{7}{|c|}{$\begin{array}{l}\text { Willing to allow use of deceased } \\
\text { family member organs or tissues } \\
\text { for research }\end{array}$} \\
\hline Male & 9.6 & 16.4 & 19.7 & 29.3 & 25.0 & \multirow[b]{2}{*}{$\chi^{2}=5.07, P=0.28$} \\
\hline Female & 11.4 & 17.4 & 23.2 & 27.7 & 20.2 & \\
\hline \multicolumn{7}{|c|}{$\begin{array}{l}\text { Agree with stem cell research using } \\
\text { adult human tissue }\end{array}$} \\
\hline Male & 26.2 & 32.5 & 27.1 & 8.2 & 6.0 & \multirow[b]{2}{*}{$\chi^{2}=12.46, P=0.014$} \\
\hline Female & 30.6 & 36.9 & 24.1 & 5.8 & 2.6 & \\
\hline \multicolumn{7}{|c|}{$\begin{array}{l}\text { Agree with stem cell research using } \\
\text { cord blood }\end{array}$} \\
\hline Male & 28.2 & 31.5 & 26.5 & 7.3 & 6.5 & \multirow[b]{2}{*}{$\chi^{2}=40.01, P<0.001$} \\
\hline Female & 40.0 & 37.6 & 14.1 & 5.6 & 2.8 & \\
\hline \multicolumn{7}{|c|}{$\begin{array}{l}\text { Agree with cloning human cells to } \\
\text { combat disease }\end{array}$} \\
\hline Male & 28.8 & 34.5 & 19.1 & 9.9 & 7.7 & \multirow[b]{2}{*}{$\chi^{2}=3.06, P=0.55$} \\
\hline Female & 28.8 & 34.4 & 20.9 & 10.7 & 5.1 & \\
\hline \multicolumn{7}{|c|}{$\begin{array}{l}\text { Not allowing own surgical tissue to } \\
\text { be used would affect relationships } \\
\text { with doctors or nurses and } \\
\text { negatively affect health care }\end{array}$} \\
\hline Male & 7.9 & 11.8 & 28.0 & 35.7 & 16.5 & \multirow{3}{*}{$\chi^{2}=5.01, P=0.29$} \\
\hline Female & 6.0 & 12.9 & 25.2 & 34.8 & 21.1 & \\
\hline Total & 7.0 & 12.3 & 26.7 & 35.3 & 18.7 & \\
\hline
\end{tabular}

aPearson chi-squared. 
an attitude scale of $1-5$ for each statement, with a percentage mean attitude score of $<60 \%$ as negative attitude and $\geq 60 \%$ as positive attitude, $68.8 \%$ of all participants had positive attitudes to the potential benefits and ethics of research and willingness to participate in this research. This positive attitude was significantly more prevalent among females $(76.1 \%)$ than among males (62.5\%), $(P<0.001)$. Regarding the specific types of genetic research such as stem cell research and cloning, over half of the participants (57.0\%) agreed that "new genetic developments will result in cures for many diseases". In relation to the ethical question "Is research on human genetics tampering with religion?", the results indicated little concern among the Saudi participants, with only a small proportion (12.2\%) agreeing that it was tampering with religion. Approval was reported for stem-cell research using cord blood $(68.1 \%)$ and or adult human tissue $(62.7 \%)$ or for cloning human cells to combat disease (63.2\%). Consistent with positive attitudes to medical and genetic research in general, only $15.8 \%$ felt that researchers were motivated by selfish reasons such as money.

The majority was willing to allow use of their tissue for research purposes (70.1\%). Consistent with this finding, only $19.3 \%$ agreed that not allowing the use of their tissues would jeopardize their relationship with doctors and nurses and have a negative effect on their health care. The majority of participants $(86.8 \%)$ indicated that they would be willing to donate blood in the future. Only $27.3 \%$ of participants reported that they would be willing to allow the use of organs or tissues of a family member after death for research purposes. Females were significantly more willing than males to allow use of their tissues for research purposes (77.0\% versus $63.9 \%, P<0.001$ ), while males ( $88.8 \%)$ were significantly more willing than women $(84.4 \%)$ to donate blood in the future $(P=0.002)$. There were no significant sex differences in relation to willingness to donate family members' organs after death $(P=0.28)$.

\section{Factors associated with attitudes to biomedical research}

Univariate analysis was conducted to identify factors which may be associated with attitude score to biomedical research (Table 4). Non-significant factors were: age (Kruskal-Wallis $\chi^{2}=$ $3.13, P=0.37)$, marital status $\left(\chi^{2}=1.06\right.$, $P=0.79)$, current employment status $\left(\chi^{2}=4.74, P=0.32\right)$, having children (Mann-Whitney $z=0.15, P=0.32$ ), perception of health status $\left(\chi^{2}=3.47, P\right.$ $=0.48)$, presence of chronic disease $(z=$ $1.21, P=0.23)$ previous tissue testing $(z$ $=0.65, P=0.51)$, previous blood donation $(z=0.16, P=0.87)$ and the desire for feedback $(z=0.73, P=0.47)$. With regard to the beliefs about medication, there was a significant inverse correlation between the total score of harm beliefs about medication and the total attitudinal score to biomedical research $(r=-0.08, P=0.026)$. However, when the harm belief was dealt as a categorical variable (high, moderate and low harm belief scorers), no such association was detected $(z=0.18, P=0.86)$.

\begin{tabular}{|c|c|c|c|c|c|c|}
\hline \multirow[t]{2}{*}{ Predictors } & \multicolumn{3}{|c|}{$\begin{array}{l}\text { Positive attitude to biomedical research } \\
\qquad(n=654 ; 68.8 \%)\end{array}$} & \multicolumn{3}{|c|}{$\begin{array}{l}\text { Willingness to allow use of excess surgical tissue } \\
\qquad(n=724 ; 78.4 \%)\end{array}$} \\
\hline & $\%$ & $\begin{array}{l}\text { Crude OR } \\
(95 \% \mathrm{CI})\end{array}$ & $\begin{array}{l}\text { Adjusted OR } \\
(95 \% \mathrm{Cl})\end{array}$ & $\%$ & $\begin{array}{l}\text { Crude OR } \\
(95 \% \mathrm{CI})\end{array}$ & $\begin{array}{l}\text { Adjusted OR } \\
(95 \% \mathrm{Cl})\end{array}$ \\
\hline \multicolumn{7}{|l|}{ Sex } \\
\hline Female & 76.1 & $1.91(1.44-2.53)$ & 2.08 (1.49-2.91) & 85.4 & $2.28(1.64-3.18)$ & $2.53(1.69-3.77)$ \\
\hline Male & 62.5 & & & 72.0 & & \\
\hline \multicolumn{7}{|c|}{ Education completed } \\
\hline$\geq$ Secondary & 59.4 & $2.13(1.39-3.28)$ & $2.06(1.23-3.46)$ & 79.2 & $1.49(0.91-2.47)$ & $1.19(0.62-2.29)$ \\
\hline$<$ Secondary & 40.0 & & & 71.8 & & \\
\hline \multicolumn{7}{|c|}{ Previous blood test } \\
\hline Yes & 57.9 & $1.47(1.06-2.05)$ & $1.61(1.09-2.37)$ & 81.3 & $2.02(1.42-2.88)$ & $2.04(1.32-3.14)$ \\
\hline No & 54.3 & & & 68.2 & & \\
\hline \multicolumn{7}{|c|}{ Previous hospitalization } \\
\hline Yes & 59.0 & $1.12(0.85-1.47)$ & $1.06(0.76-1.47)$ & 83.1 & $1.78(1.30-2.45)$ & $1.56(1.06-2.30)$ \\
\hline No & 55.4 & & & 73.3 & & \\
\hline \multicolumn{7}{|c|}{ Previous participation in health-related research } \\
\hline Yes & 68.1 & $1.56(1.09-2.25)$ & $1.65(1.06-2.55)$ & 82.4 & $1.37(0.91-2.07)$ & $1.99(1.16-3.41)$ \\
\hline No & 54.3 & & & 77.3 & & \\
\hline
\end{tabular}

$O R=$ odds $; C I=$ confidence interval . 
Applying logistic regression analysis the significant predictors of a positive attitude to biomedical research were: sex, education, having had a previous blood test and previous participation in health-related research. Females (adjusted OR $=2.08,95 \%$ CI: 1.49-2.91, $P$ $<0.01)$ and those who had completed secondary education $(\mathrm{aOR}=2.06,95 \%$ CI: $1.23-3.46, P<0.01)$ were twice as likely to have a positive attitude. Participants with a history of previous blood test $(\mathrm{aOR}=1.61,95 \% \mathrm{CI}: 1.09-2.37$, $P<0.05)$ ), as well as those who previously participated in health-related research $(\mathrm{aOR}=1.65,95 \% \mathrm{CI}: 1.06-2.55$, $P<0.05)$ were 1.5 times more likely to have a positive attitude.

Univariate analysis was conducted to identify factors that may be associated willingness to allow use of excess surgical tissue for research (Table 4). Non-significant factors were: age (Kruskal-Wallis $\chi^{2}=0.27, P=0.97$ ), marital status $\left(\chi^{2}=0.38, P=0.95\right)$, current employment status $\left(\chi^{2}=1.88\right.$, $P=0.76$ ), having children (MannWhitney $z=0.72, P=0.49$ ), perception of health status $\left(\chi^{2}=4.07, P=0.41\right)$, presence of chronic disease $(z=1.24, P$ $=0.22)$, previous tissue testing $(z=0.96$, $P=0.34)$, previous blood donation $(z=$ $0.01, P=0.99)$, belief about medications $(z=0.92, P=0.35)$ and the desire for feedback $(z=1.15, P=0.62)$.

Applying logistic regression analysis, the significant predictors of willingness to allow use of excess surgical tissue were: sex, history of previous blood test and history of previous hospitalization. Females $(\mathrm{aOR}=2.53,95 \% \mathrm{CI}$ : $1.69-3.77, P<0.01)$, those with history of previous blood test $(\mathrm{aOR}=2.04,95 \%$ CI: $1.32-3.14, P<0.01)$, those with history of previous hospitalization $(\mathrm{aOR}$ $=1.56,95 \%$ CI: $1.06-2.30, P<0.01)$ as well as those who had previously participated in health-related research (aOR $=1.99,95 \%$ CI: $1.16-3.41, P<0.01)$ were about twice as likely to allow their excess surgical parts to be used for research purposes.

\section{Discussion}

There has been little, if any, research examining the circumstances under which Saudi Arabian people would be willing to allow epidemiological investigators to use their private information and biological samples for research. Attitudes to biomedical research were evaluated in this study using a set of statements regarding the potential benefits and ethics of research. Overall, $68.8 \%$ of participants reported positive attitudes towards biomedical research. This satisfactory level of positive attitude might be justified by the fact that many of those interviewed had previously engaged with the health care system and reported various health care experiences. Female participants were more engaged with the health care system, and this may be why females reported more willingness to allow use of excess surgical parts for research purposes.

Genetic research is multi-dimensional and there has been considerable controversy surrounding certain types of research such as stem-cell research. Over half of our participants (57\%) agreed that new genetic developments would result in cures for many diseases. This figure is less than that of a recent Human Genetics Commission report from the United Kingdom of attitudes to human genetic information, where 88\% agreed with this statement [18].

Islam encourages furthering our understanding of some hereditary diseases and our susceptibility to them, under the condition that research upholds the dignity of humanity [12]. The results of the present study indicated no concern among our Saudi participants. Consistent with positive attitudes to medical and genetic research in general, only $16 \%$ felt that researchers were motivated by selfish reasons such as money. In contrast, a Dutch study comparing cancer trial participants and non-participants towards clinical research, found that $34 \%$ of participants and $23 \%$ of non-participants believed that medical research was primarily performed to promote doctors' careers [19].

With regard to the willingness to contribute to research, the majority of participants had never donated blood. However, the majority of participants (87\%) indicated that they would be willing to donate blood in the future. This high level of willingness is consistent with that found in a national study of the Swedish public [20] and a nationally representative study of households in the United States [21]. Moreover, when interviewed subjects were presented with the hypothetical situation of having surgery and subsequently being asked if their "excess" surgical tissue (i.e. material which was properly removed as part of surgery and which is surplus to that needed to be stored/tested for patient care purposes) could be used in a research study, the majority was willing to allow such use of their tissue. Similarly, a Swedish study of 1000 participants found that $71 \%$ of participants would agree to the use of a donated tissue sample for genetic research [22].

Patients may feel obliged to comply with doctors' request to allow their tissue to be used and stored for research almost without regard for personal preferences due to a perceived dependence on the doctor for their well-being. However, the present study revealed that only $19.3 \%$ participants agreed that their health care would be affected if not they did not allow the use of their tissues. This finding was in agreement with that of Kettis-Lindblad et al. [20]. On the other hand, it was clear that the participants were less willing to allow the use of tissue or organs from a deceased relative than they were to allow their own excess surgical tissue to be used. The decision to donate organs is often ultimately made by family members. However, further research is necessary to identify the symbolic differences between donation of tissue from the living and from the dead.

It would appear that in general the public would like some level of personal 
feedback of their results. In a study in Ireland the majority of participants reported that they would like to receive general information regarding the results of the research if they allowed blood or tissue samples to be used for research [4]. However, it was interesting that only $12 \%$ of respondents in our study indicated that they would like to receive such information, and there was no significant association between the desire for feedback and either the attitude to biomedical research or willingness to donate their tissues for research purposes.

In other studies the characteristics of those in favour of donation include being older [23], being highly educated and having a more positive attitude toward medical and genetic research [20,24]. However, this was not the case in the present study, where those who had completed their secondary education were not significantly more in favour of donation than non-educated, but were twice as likely to have a positive attitude to biomedical research.

In a previous study, the highest proportion of potential donors was reported among those who had previously donated blood in the past [20]. However, in our study, previous blood testing - and not blood donation - was a significant predictor of both the attitude to biomedical research and the willingness to donate tissues. Similarly, participants who reported ever being a hospital inpatient were significantly more in favour of donation than those without a history of previous hospitalization.

Prior participation in medical research has been found to positively influence willingness to participate in such research [14]. In the present study, those who had previously participated in health-related research were more willing to allow use of their surgical parts and to have a positive attitude to biomedical research.

It is also possible that a person's attitude towards medicines in general may affect his/her willingness to participate in biomedical research and to allow stored tissue to be used in such research $[16,25]$. In the present study, there was a slight tendency of participants to agree with the general harm concept that medicines are harmful. This tendency could have lead to a reduced willingness to contribute to medical research. However, although there was a significant inverse correlation between the total score of harm beliefs about medicines and the total attitudinal score to biomedical research ( $r=-0.08, P=0.026)$, this significant correlation disappeared after adjusting for sex and other factors.

The present study had some limitations. First, the subjects of the studywere from outpatient clinics, and if they had been from a different environment, e.g. at their workplace, completely different results might be expected. Secondly, the participants that we interviewed were recruited from only one city, and it is possible that regional differences could affect our results, and the attitudes expressed in the interviews may not be representative of the general public within Saudi Arabia. In addition, many of those interviewed had been engaged with the health care system and reported various health care experiences such as blood tests, tissue tests and being a hospital inpatient. This fact must have affected the attitude of participants, especially females, who were more engaged in the health care system than males.

\section{Conclusion}

Our participants were generally quite supportive of medical research, with high levels of willingness to contribute excess surgical tissue for research and storage. This willingness does not depend on the subjects being well-informed and having trust in experts and institutions. These findings suggest that the attendants of outpatient clinics in Riyadh were generally aware of and committed to making a contribution to research and related activities in the health care system for their own benefit and for the benefit of future patients. However, we need to validate our findings through research with a nationally representative sample of Saudi Arabians.

\section{References}

1. Kaiser J. Biobanks. Population databases boom, from Iceland to the U.S. Science, 2002, 298:1158-1161.

2. Burton JL, Wells M. The Alder Hey affair. Archives of Disease in Childhood, 2002, 86:4-7.

3. Tutton R, Kaye J, Hoeyer K. Governing UK Biobank: the importance of ensuring public trust. Trends in Biotechnology, 2004, 22:284-285.

4. Cousins G et al. Public perceptions of biomedical research: a survey of the general population in Ireland. Psychology reports. Dublin, Royal College of Surgeons in Ireland, 2005.

5. Kettis-Lindblad A et al. Genetic research and donation of tissue samples to biobanks. What do potential sample donors in the Swedish general public think? European Journal of Public Health, 2006, 16:433-440.
6. McQuillan GM et al. Consent for genetic research in a general population: the NHANES experience. Genetics in Medicine, 2003, 5:35-42.

7. Merz JF, Sankar P. DNA banking: an empirical study of a proposed consent form. In: Weir RF, ed. Stored tissue samples: ethical, legal, and public policy implications. lowa, University of lowa Press, 1998:198-225.

8. Wang SS et al. Public attitudes regarding the donation and storage of blood specimens for genetic research. Community Genetics, 2001, 4:18-26.

9. Malone T et al. High rate of consent to bank biologic samples for future research: the Eastern Cooperative Oncology Group experience. Journal of the National Cancer Institute, 2002, 94:769-771. 
10. Wong ML et al. Willingness to donate blood samples for genetic research: a survey from a community in Singapore. Clinical Genetics, 2004, 65:45-51.

11. Biobanking in British Columbia. A deliberative public consultation. GE3LS Arch Project, W. Maurice Young Centre for Applied Ethics, University of British Columbia [website] (http:// biobanktalk.ca/, accessed 30 March 2011).

12. Seminar on genetics, genetic engineering, the human genes, and genetic treatment: an Islamic perspective. Islamic Organisation for Medical Sciences (http://www.islamset.com/bioethics/ genetics/genetics.html, accessed 30 March 2011).

13. Saudi Biobank. King Abdullah International Medical Research Center [website] (http://www.kaimrc.med.sa/, accessed 30 March 2011).

14. Trauth JM et al. Public attitudes regarding willingness to participate in medical research studies. Journal of Health \& Social Policy, 2000, 12:23-43.

15. Abolfotouh MA et al. Smoking intervention program for secondary school male students in the Southwestern Saudi Arabia. Eastern Mediterranean Health Journal., 1997, 3:90-100.

16. Horne R, Weinman J, Hankins M. The beliefs about medicines questionnaire: the development and evaluation of a new method for assessing the cognitive representation of medication. Psychology and Health, 1999, 14:1-24.

17. Horne R et al. Medicine in a multi-cultural society: the effect of cultural background on beliefs about medications. Social Science \& Medicine, 2004, 59:1307-1313.
18. Public attitudes to human genetic information. People's panel quantitative study conducted for the human genetic commission. London, Human Genetics Commission, 2001.

19. Madsen SM et al. Attitudes towards clinical research amongst participants and nonparticipants. Journal of Internal Medicine, 2002, 251:156-168.

20. Kettis-Lindblad A et al. Genetic research and donation of tissue samples to biobanks. What do potential sample donors in the Swedish general public think? European Journal of Public Health, 2006, 16:433-440.

21. McQuillan GM et al. Consent for genetic research in a general population: the NHANES experience. Genetics in Medicine, 2003, 5:35-42.

22. Hoeyer $\mathrm{K}$ et al. Informed consent and biobanks: a population-based study of attitudes towards tissue donation for genetic research. Scandinavian Journal of Public Health, 2004, $32: 224-229$.

23. Malone T et al. High rate of consent to bank biologic samples for future research: the Eastern Cooperative Oncology Group experience. Journal of the National Cancer Institute, 2002, 94:769-771.

24. Wang SS et al. Public attitudes regarding the donation and storage of blood specimens for genetic research. Community Genetics, 2001, 4:18-26.

25. Horne R. Assessing perceptions of medication: psychological perspectives. In: McGovock $\mathrm{H}$, ed. Handbook of drug use research methodology. Newcastle, United Kingdom, Drug Utilisation Research Group, 2000:299-319.

\section{Operational guidelines for ethics committees that review biomedical research}

All biomedical research involving human subjects has to comply with established international guidelines that require ethical and scientific review of the research, alongside informed consent. This book sets out operational guidelines for ethics committees in order to facilitate, support, and ensure quality of the ethical review of biomedical research in all countries around the world.

Targeted for use by national and local bodies, these guidelines define the role and constituents of an ethics committee, and detail the requirements for submitting an application for review. The review procedure, plus details of the decision making process are provided, together with necessary follow-up and documentation procedures.

The document is available in a number of languages, including English and French, and can be downloaded at: http://apps.who.int/tdr/svc/publications/training-guideline-publications/operational-guidelines-ethics-biomedicalresearch.htm 